\title{
Implementasi Kebijakan Disiplin Pegawai Negeri Sipil Di Balai Latihan Kerja Mandiri Provinsi Jawa Barat
}

\author{
${ }^{1}$ Sahya Anggara, ${ }^{2}$ Mohamad Ichsana Nur, ${ }^{3}$ Ahmad Daroni \\ ${ }^{1}$ Administrasi Publik Fakultas Ilmu Sosial dan Ilmu Politik UIN Sunan Gunung Djati Bandung; \\ sahyaanggara@uinsgd.ac.id \\ ${ }^{2}$ Administrasi Publik Fakultas Ilmu Sosial dan Ilmu Politik UIN Sunan Gunung Djati Bandung; \\ 22mochihsananoor@gmail.com \\ ${ }^{3}$ Administrasi Publik Fakultas Ilmu Sosial dan Ilmu Politik UIN Sunan Gunung Djati Bandung; \\ ahmaddaroni1@gmail.com
}

\begin{abstract}
The purpose of this study was to determine the policy implementation of Government Regulation Number 53 of 2010 concerning Discipline of Civil Servants at the Independent Training Center of West Java Province. The method in this reseach used is descriptive qualitative method. In this study, researchers examined the implementation of policy, the researchers used the theory of policy implementation model Edward III in Widodo (2017) about four factors that play an important role in achieving successful implementation, namely communication, resources, disposition, and bureaucratic structure. Data were obtained through observation, interviews, documentation, and library studies and using data analysis techniques according to Miles and Huberman. The results of the study, the Implementation of Government Regulation Number 53 of 2010 concerning Discipline of Civil Servants at the West Java Provincial Independent Training Center has not run optimally. First, communication has gone well because of the distribution of the regulations to the staff. Second, the resources are not optimal because the number of human resources in the West Java Province Independent Training Center is still lacking and the preparedness needs to be improved. Third, the disposition has been well seen from the willingness of the Employees to attend the morning rally, obey working hours, and carry out tasks responsibly. Fourth, the bureaucratic structure has been effective because the West Java Provincial Training Center already has Standard Operating Procedures and clear fragmentation procedures.
\end{abstract}

Keywords: Policy Implementation, Discipline, Civil Servants.

\section{Pendahuluan}

Salah satu instrumen pemerintah dalam meningkatkan kedisiplinan Pegawai Negeri Sipil (PNS) adalah dengan dikeluarkannya Peraturan Pemerintah Nomor 53 Tahun 2010 tentang Disiplin Pegawai Negeri Sipil. Peraturan ini dibentuk dengan maksud untuk mendisiplinkan kinerja sesuai dengan kewajiban yang tertera dalam peraturan yang ada. Pegawai Negeri Sipil adalah salah satu instrumen yang haeus dimanfaatkan dengan maksimal. Namun, masih banyak PNS yang melanggar aturan yang ada seperti terlambat, pulang diwaktu yang tidak tepat, dan pelanggaran lain sehingga dalam pelayanannya tidak efektif.

PNS yang menyimpang dari PP Nomor 53 Tahun 2010 tentang Disiplin PNS kerap didapati, namun penegakan kedisiplinan aparatur pemerintah masih menjadi tantangan tersendiri. Pasalnya, kerap terjadi pelanggaran disiplin yang pada akhirnya menjadi faktor PNS diberhentikan. Asman Abnur, sebagai Menteri Aparatur Sipil Negara dan Reformasi 
Birokrasi di Era Pemerintahan Susilo Bambang Yudhoyono (SBY), menyebutkan pelanggaran disiplin yang kerap ditemukan adalah membolos lebih dari 46 hari. Ini menjadi peringatan bagi seluruh ASN. Maka diadakannya beberapa sanksi untuk pelangar seperti penurunan pangkat dan pemberhentian.

Moenir (2002) berpendapat bahwa yang dimaksud dengan disiplin adalah bentuk ketaatan terhadap suatu aturan, baik berupa aturan tertulis maupun tidak, yang telah ditetapkan. Sedangkan Handoko (2014) menyebut disiplin merupakan suatu manajemen untuk menjalankan manajemen standar organisasional. Kemudian, jika melihat pada Kamus Besar Bahasa Indonesia, bahwa pegawai memiliki arti sebagai orang yang bekerja pada sebuah organisasi, sedangkan negeri adalah negara atau pemerintah. Sehingga secara bahasa PNS dapat dikatakan sebagai seseorang yang bekerja pada pemerintah negara.

Mazmanian dalam Agustino (2014) memberikan pengertian implementasi kebijakan sebagai keputusan kebijaksanaan dasar yang dijalankan dan pada umumnya dapat berbentuk semacam undang-undang, himbauan dan perintah, serta keputusan lembaga eksekutif atau lembaga yudikatif. Sedangkan Van meter dan Van Horn dalam Agustino (2014), memaknai implementasi kebijakan public yaitu suatu sikap dan tindakan yang dijalankan lembaga oleh publik atau swasta, perorangan atau kelompok-kelompok pemerintah yang diperuntukan untuk pencapaian suatu tujuan. Wahab (2012) juga berpendapat bahwa implementasi kebijakan ialah bentuk pengoprasionalisasian atau serangkaian aktivitas yang diselenggarakan berdasarkan pada apa yang telah disepakati, digariskan, dan ditetapkan oleh peraturan hukum seperti undang-undang. Karena telah diatur dalam undang-undang tersebut, maka setiap secara sinergis dan kolaboratif digerakkan untuk bisa bekerjasama dalam menjalankan kebijakan atau program tertentu yang dikehendaki. Selain itu, Nugroho (2004) juga menjelaskan bahwa implementasi kebijakan pada dasarnya merupakan suatu alat atau media kebijakan dalam rangka untuk mencapai sasaran dan tujuannya.

Implementasi kebijakan sendiri memiliki model tertentu terdiri dari berbagai macam model, di mana dengan adanya model ini akan menunjukkan faktor-faktor yang saling berhubungan dalam mengukur keberhasilan implementasi kebijakan. Peneliti menggunakan Teori Edward III dalam Subarsono (2013) yang menyebutkan 4 faktor yang mempengaruhi implementasi kebijakan yang diantaraya meliputi a) komunikasi, yaitu apabila pemangku kebijakan mengetahui hal apa yang harus dilakukan dan apa yang menjadi sasaran dari kebijakan sehingga mengurangi penyimpangan dan penyalahgunaan implementasi, b) sumber daya, yaitu ketersediaan sumber daya manusia yang meliputi kompetensi pemangku kebijakan dan sumber daya finansial, c) disposisi, yaitu apabila pelaksana kebijakan memiliki perspektif maupun sikap yang sejalan atau selaras dengan pemangku kebijakan, maka implementasi kebijakan juga akan menjadi efektif, d) struktur birokrasi, sebagai mekanisme kerja yang dibentuk untuk mengelola pelaksanaan sebuah kebijakan. Yang pada implementasinya menekankan kepada SOP yang ada sehingga pelaksanaan dari suau kegiatan berjalan dengan baik. Edward III dalam Subarsono (2013) mengatakan bahwa jika terlalu panjang strutur birokrasi maka akan terjadi red-tape, yakni prosedur birokrasi yang rumit dan kompleks.

Dalam rangka menjaga ketertiban dan keberhasilan penyelenggaraan tugas pokok dan fungsi setiap pegawai ASN di lingkungan kerjanya masing-masing, maka Pemerintah Pusat mengeluarkan suatu PP Nomor 53 Tahun 2010 tentang Disiplin Pegawai Negeri Sipil. Peraturan tersebut mengandung kewajiban, larangan, dan beberapa sanksi yang diberlakukan ketika terjadi pelanggaran. Secara lebih jelas, bahwa dalam pasal 1 ayat (1) diberikan pemahaman tentang disiplin pegawai negeri sipil, yaitu kesiapsiagaan para Pegawai Negeri 
Sipil untuk senantiasa mematuhi segala bentuk kewajiban dan menjauhi segala bentuk larangan yang telah digariskan oleh peraturan hukum seperti peraturan perundang-undangan dan/atau peraturan kedinasan, dan apabila melanggarnya maka patut unutk diberikan hukuman disiplin. Jika melihat pada peraturan tersebut, sudah sangat jelas disebutkan bahwa semua Pegawai Negeri Sipil wajib menjunjung tinggi disiplin PNS.

PNS yang terbukti tidak menaati Peraturan Pemerintah No. 53 Tahun 2010 maka mereka dianggap telah melakukan pelanggaran. Pelanggaran disiplin sendiri dijelaskan pada Pasal 1 ayat (3) PP No.53 Tahun 2010 yang pada intinya menyebutkan bahwa pelanggaran merupakan segala sesuatu bentuk ketidak patuhan, tidak melakukan kewajiban sebagai PNS baik tertulis atau tidak dan dilakukan baik dalam jam kerja atau tidak. Yang melanggar peraturan yang ada maka akan mendapatkan sanksi. Yang mana menurut pasal 1 angka 4 dari Peraturan Pemerintah Nomor 53 Tahun 2010, disebutkan bahwa yang dimaksud dengan hukuman disiplin adalah "hukuman yang dijatuhkan kepada Pegawai Negeri Sipil karena melanggar Peraturan Disiplin Pegawai Negeri Sipil”. Dimana sanksi diberlakukan bertujuan untuk membina, dan senantiasa meningkatkan kinerja yang ada.

Berdasarkan observasi pra-penelitian yang dilakukan di Balai Latihan Kerja Mandiri (BLKM) Provinsi Jawa Barat pada tanggal 18 Juni sampai 16 Juli 2018, masih terdapat pegawai yang tidak mematuhi jam kerja, masih terdapat pegawai yang tidak melaksanakan apel pagi, masih terdapat pegawai yang keluar dalam waktu yang tidak tepat, dan masih kurangnya kepedulian sebagian pegawai dalam menggunakan jam kerja secara optimal. Berdasar latar belakang permasalahan tersebut, maka peneliti kemudian tertaraik untuk melakukan penelitian dengan tujuan untuk menganalisis implementasi kebijakan peraturan pemerintah nomor 53 tahun 2010 tentang disiplin pegawai negeri sipil di Balai Latihan Kerja Mandiri Provinsi Jawa Barat).

\section{Metode Penelitian}

Dalam melaksanakan penelitian ini, peneliti memandang bahwa perlu menggunakan paradigma kualitatif berserta tipe penelitian deskriptif. Hal ini ditujukan untuk memberi gambaran mengenai implementasi kebijakan PP Nomor 53 Tahunu 2010 tentang Disiplin PNS di BLKM Provinsi Jawa Barat. Dalam menggunakan sumber data, peneliti mengumpulkannya dalam bentuk data yang bersifat primer dan data sekunder. Oleh karenanya, peneliti dalam usaha memperoleh data penelitian, memanfaatkan wawancara secara mendalam dan terstruktur. Dalam proses wawancara ini, peneliti melakukannya kepada pihak Balai Pelatihan Kerja Mandiri Jawa Barat seperti Kepala BLKM kabid, dan pegawai lainnya yang terkait. Selain itu, teknik pengumpulan data lainnya adalah dengan melakukan studi dokumen dan kepustakaan, yaitu berupa menganalisis beberapa buku, artikel, peraturan, arsip, data rekapitulasi yang berhubungan dengan implementasi kebijakan PP Nomor 53 tahun 2010 tentang Disiplin PNS di Balai Latihan Kerja Mandiri (BLKM) Provinsi Jawa Barat. Dalam melakukan analisis data, penelitian ini menggunakan analisis data kualitatif model interaktif (Miles dan Huberman, 2009: 20). Dimana dalam analisi data meliputi tiga kegiatan yaitu peneliti perlu melakukan pengurangan (reduksi) data, melakukan penyajian data yang telah dipilah dan dipilih, sampai akhirnya pada proses penarikan kesimpulan. 


\title{
Hasil Dan Pembahasan
}

Penelitian yang berjudul implementasi Peraturan Pemerintah Nomor 53 tahun 2010 tentang Disiplin Pegawai Negeri Sipil di Balai Latihan Kerja Mandiri Provinsi Jawa Barat ini menghasilkan temuan dan pembahasan sebagai berikut:

a. Komunikasi

Kepala BLKM Provinsi Jawa Barat mengatakan bahwa koordinasi yang dilakukan untuk pengimplementasian Peraturan Pemerintah Nomor 53 Tahun 2010 di Balai Latihan Kerja Mandiri Provinsi Jawa Barat, berikut pernyataan Kepala BLKM Provinsi Jawa Barat:

"Dalam implementasi PP No 53 tahun 2010 tentang disiplin PNS, pada Bab 1 PP tersebut ada ketentuan tentang PNS bahwa PNS ini setiap lisan tulisan perbutan harus sejalan dengan peraturan disiplin PNS yang sudah menjadi kewajibannya, dan apabila melanggar maka akan dijatuhi hukuman sesuai dengan PP tersebut. Jadi koordinasinya itu berupa PP tersebut yang merupakan suatu wujud komunikasi yang harus dibaca, diketahui, dipahami, dan dipatuhi oleh setiap PNS. Dalam pelaksanaan koordinasi disiplin PNS di BLKM ini dari kepala bidang masing-masing, kepala bidang ke Kasubag TU, lalu Kasubag TU ke Kepala BLKM. Jadi di sini kepala seksi yang tentunya lebih awal mengetahui kedisiplinan bawahannya dan yang lebih mengetahui pastinya apabila ada masalah perihal kedisiplinan." (Senin, 11 Maret 2019 Pukul 13.00 di BLKM Provinsi Jawa Barat).

Kemudian Kepala BLKM Provinsi Jawa Barat mengatakan bahwa sosialisasi selalu dilaksanakan untuk meningkatkan pemahaman pegawai mengenai PP Nomor 53 tahun 2010 tentang Disiplin Pegawai Negeri Sipil di Balai Latihan Kerja Mandiri Provinsi Jawa Barat biasanya mengingatkan pegawai untuk meningkatkan kedisiplinan pada pelaksanaan apel pagi, sebagaimana yang dikemukakan beliau:

\begin{abstract}
"Semua pegawai yang ada di BLKM sudah semestinya tahu dan melaksanakan aturan ini, dan sosialisasi mengenai PP ini sangat diperlukan untuk memberikan pemahaman kepada para pegawai dan tidak cukup sekali dua kali saja, namun perlu sering diingatkan kepada pegawai akan pentingnya mematuhi aturan disiplin PNS. Seperti halnya di BLKM ini pada apel pagi biasa disampaikan, diingatkan terkait untuk meningkatkan kedisiplinan walauun itu tidak setiap hari disampaikan setidaknya ada waktu atau momen yang bisa digunakan untuk sosialisasi disiplin PNS." (Senin, 11 Maret 2019 Pukul 13.00 di BLKM Provinsi Jawa Barat).
\end{abstract}

Dengan demikian, dimensi komunikasi dalam implementasi PP Nomor 53 tahun 2010 tentang Disiplin Pegawai Negeri Sipil di Balai Latihan Kerja Mandiri Provinsi Jawa Barat sudah berjalan karena adanya pendistribusian peraturan tersebut sampai kepada staf atau pegawai. Hal ini ejalan dengan teori Edward III yang menyebutkan dalam implementasi kebijakan perlu adanya penyampaian gagasan kepada pihak eksekutor. 


\section{b. Sumber Daya}

Dalam dimensi sumber daya ini yang berkaitan dengan implementasi PP Nomor 53 Tahun 2010 tentang Disiplin Pegawai Negeri Sipil, peneliti mengambil tiga indikator sumber daya yaitu sumber daya manusia, sarana dan prasarana, serta biaya dan anggaran.

Pertama, mengenai sumber daya manusia Pegawai Negeri Sipil di Balai Latihan Kerja Mandiri Provinsi Jawa Barat, berikut yang dikemukakan oleh Kepala BLKM Provinsi Jawa Barat:

"SDM dengan jumlah yang ada dari jumlah pegwai secara kinerja kekurangan pegawai, sehingga kita memerlukan tenaga kerja operator untuk membantu dari SDM di sini karena volume kerja di BLKM banyak sekali tentang pelatihan-pelatihan, kesiapan PNS harus siap karena sudah tugasnya dia dan tugas pokok dia ya hrus siap, kalau tidak siap ya harus keluar, nanti dicap kinerjanya tidak tercapai, selalu atasan menilai dari kinerjanya tersebut." (Senin, 11 Maret 2019 Pukul 13.00 di BLKM Provinsi Jawa Barat).

Selanjutnya Ibu Eli Sugriwati, SE menjelaskan bahwa perlu ditingkatkan lagi perihal kesiapan SDM, berikut pernyataan beliau:

"PNS di BLKM tentunya merupakan SDM mengenai implementasi PP Nomor 53 tahun 2010 ini, perihal kesiapan pegawai perlu ditingkatkan lagi karena ketentuan masuk kerja pukul 07.30 WIB ada toleransi sampai 08.00 WIB dan apel pagi setiap hari dilaksanakan setiap pukul 08.00 WIB, yang mana apabila terdapat pegawai yang tidak mengikuti apel pagi akan mendapatkan teguran dan tentunya akan dipanggil atasan.” (Senin, 11 Maret 2019 Pukul 14.40 di BLKM Provinsi Jawa Barat).

Sementara itu, masih senada dengan pendapat di atas yang mana perlu ditingkatkan perihal kesiapan Pegawai Negeri Sipil, yang mana Bapak Mulyana, S. Sos menyebutkan Pegawai Negeri Sipil yang ada belum sepenuhnya mematuhi Pertauran Pemerintah tentang Disiplin Pegawai Negeri Sipil, berikut adalah pernyataannya:

"Berkaitan dengan SDM, yang mana PNS BLKM sudah baik dalam melaksanakan kedisiplinan namun masih saja ada pegawai yang belum sepenuhnya mematuhi dari peraturan tersebut seperti halnya pada jam kerja dimana masih terdapat pegawai yang belum mematuhi jam kerja, maka di sinilah perlu suatu ketegasan dari atasan sebagai salah satu upaya untuk meningkatkan kedisiplinan pegawai di sini." (Senin, 11 Maret 2019 Pukul 14.50 di BLKM Provinsi Jawa Barat).

Kedua, mengenai sarana dan prasarana, peneliti menanyakan bagaimana sarana dan prasarana yang ada untuk penunjang implementasi suatu kebijakan. Berikut pernyataan dari Kepala BLKM Provinsi Jawa Barat:

"Kalau dilihat dari sarana dan prasarana yang ada di BLKM ini yang menunjang disipliin PNS kita di sini disediakan kendaraan dinas untuk melaksanakn tugas dinas misalnya, juga kita di sini absen menggunakan henki (absen elektronik) yang mana absen ini bisa langsung diakses oleh BKD tiap bulannya, yang mana di situ nanti akan terlihat bagus tidaknya disiplin pegawai dari segi kehadiran dan mematuhi jam kerja. Namun kini telah hadir aplikasi 
baru yang bernama Kimop yang lebih efektif, efisien dan akurat untuk absensi. Selain itu, dengan adanya CCTV di ruangan kerja walaupun tidak semua sudut ada CCTV setidaknya bisa menunjang PNS untuk tetap disiplin dan tanggungjawab dalam menjalankan tugasnya." (Senin, 11 Maret 2019 Pukul 13.00 di BLKM Provinsi Jawa Barat)

Selanjutnya pernyataan dari Ibu Eli Sugriwati, SE yang menyebutkan bahwa sarana dan prasarana di Balai Latihan Kerja Mandiri yang mendukung disiplin Pegawai Negeri Sipil sudah lengkap, berikut pernyataannya:

"Kita sarana dan prasarana sudah lengkap telah dipenuhi oleh pusat, BKD. Mulai dari finger Print, absen manual, komunikasi dengan dinas itu sudah lengkap, adapaun kendaraan dinas juga sudah ada baik itu kendaraan untuk pelatihan ke berbagai daerah, mobil dinas, dan motor dinas telah disediakan." (Senin, 11 Maret 2019 Pukul 14.40 di BLKM Provinsi Jawa Barat).

Ketiga, menegnai biaya dan anggaran, berikut pernyataan dari Kepala BLKM Provinsi Jawa Barat:

"Biaya ataupun anggaran untuk implementasi disiplin PNS di BLKM ini tentunya bersumber pada APBD Provinsi Jawa Barat melalui Badan Kepegawaian Daerah (BKD) Provinsi Jawa Barat melalui sosialisasi, di mana perwakilan dari BLKM yang pada biasanya diwakili oleh Pengadministrasi Umum Kepegawaian Subbag TU mengikuti sosialisasi sekaligus diberikan pengarahan dan pemahaman mengenai implementasi PP Nomor 53 tahun 2010 tentang Disiplin PNS. ” (Senin, 11 Maret 2019 Pukul 13.00 di BLKM Provinsi Jawa Barat).

Selanjutnya Bapak Ir. Joko Widada menyatakan bahwa biaya dan anggaran di Balai Latihan Kerja Mandiri sudah menunjang, salah satunya adalah dengan adanya pemberian Insentif Berbasis Kinerja (IBK) kepada pegawai yang memiliki tingkat disiplin dan kinerja yang tinggi, berikut pernyataannya:

"Menurut saya biaya yang menunjang disiplin PNS sudah menunjang dari anggaran yang ada, misalnya dengan memberikan insentif kepada pegawai untuk memberikan motivasi dalam disiplin, khususnya lagi kan sekarang itu ada yang namanya IBK (Insentif Berbasis Kinerja) yang mana setiap bulannya ada pemberian insentif khusus kepada pegawai yang memiliki kinerja dan kedisiplinan yang tinggi. Terkadang juga di sini ada dana khusus jikalau melakukan tugas dinas keluar." (Senin, 11 Maret 2019 Pukul 14.10 di BLKM Provinsi Jawa Barat).

Dengan demikian, dimensi sumber daya dalam implementasi PP Nomor 53 tahun 2010 tentang Disiplin Pegawai Negeri Sipil di Balai Latihan Kerja Mandiri Provinsi Jawa Barat dapat dikatakan optimal karena walaupun sarana dan prasarana serta biaya dan anggaran telah menunjang sumber daya manusia yang ada belum menunjang hal ini karena jumlah pegawai masih kurang dan kesiapanya pun perlu ditingkatkan. 
c. Disposisi

Dimensi disposisi ini peneliti bagi ke dalam dua indikator yaitu pemahaman dan respon pegawai. Pertama, pemahaman pelaksana kebijakan Jawa Barat, berikut pernyataan dari Kepala BLKM Provinsi Jawa Barat:

"Sudah menjadi suatu keharusan seorang PNS memahami PP Nomor 53 tahun 2010 tentang Disiplin PNS, ya jikalau pegawai tersebut tidak paham maka dia tidak akan disiplin. Kalau dipersentasekan pemahaman PNS di sini sudah ada yang mencapai $90 \%$ ada juga yang baru sampai $75 \%$ tergantung orangnya, dengan berpatokan pada kedisiplinan pegawai yang bersangkutan. Kalau dirata-ratakan mungkin pemahaman pegawai PNS di sini terkait PP Nomor 53 tahun 2010 tentang Disiplin PNS sampai pada 85\%.” (Senin, 11 Maret 2019 Pukul 13.00 di BLKM Provinsi Jawa Barat).

Sementara itu, menurut Ibu Eli Sugriwati, SE pemahaman terkait PP Nomor 53 tahun 2010 tentang Disiplin Pegawai Negeri Sipil sudah bagus, berikut yang pernyataannya:

"Menurut saya pribadi, pemahaman pegawai terkait Peraturan Disiplin PNS sudah bagus dilihat daripada bagaimana pegawai itu melaksanakan tugas dan dari mematuhi peraturan disiplin salah satunya. Namun mungkin memang yang namanya manusia tidak luput dari kesalahan dan lupa ya memang masih ada pegawai yang belum optimal dalam mematuhi jam kerja sehingga waktu yang digunakanpun belum optimal. Hal ini pun sebenarnya sering diingatkan oleh atasan baik pada apel pagi maupun pada pegawai yang bersangkutan apabila melakukan pelanggaran." (Senin, 11 Maret 2019 Pukul 14.40 di BLKM Provinsi Jawa Barat).

Kedua, respon pelaksana kebijakan Berikut pernyataan dari Kepala BLKM Provinsi Jawa Barat terkait dukungan Pegawai Negeri Sipil terhadap implementasi PP Nomor 53 tahun 2010 tentang Disiplin Pegawai Negeri Sipil:

"Respon pegawai di sini sangat mendukung dengan adanya PP disiplin PNS tersebut. memang pada awalnya pp ini dirasa berat karena dilihat daripada hukumannya dimana terdapat hukuman ringan, sedang, dan berat. Namun karena itu sudah menjadi aturan dan kewajiban, maka mau tidak mau PNS harus siap dan harus mendukung. Dimana salah satu bentuk dukungannya para pegawai di sini mengikuti apel pagi, mematuhi jam kerja, dan melaksanakan tugas dengan penuh tanggungjawab dan bekerja secara optimal." (Senin, 11 Maret 2019 Pukul 13.00 di BLKM Provinsi Jawa Barat).

Bapak Ir. Joko Widada menyatakan bahwa pegawai mendukung dalam implementasi PP No. 53 tahun 2010 sudah merupakan suatu komitmen. Berikut yang pernyataannya:

"Pegawai BLKM tetap mendukung dengan adanya pelaksanaan PP ini karena sudah menjadi komitmen karena kita butuh kantor, sudah menjadi suatu kewajiban kita untuk mematuhi aturan kantor dan tidak melanggar aturan kantor. Menurut saya tidak ada alasan untuk menolak peraturan PP disiplin tersebut. mau tidak mau sebagai PNS harus mematuhi 
peraturan tersebut." (Senin, 11 Maret 2019 Pukul 14.10 di BLKM

Provinsi Jawa Barat).

Dengan demikian, untuk dimensi disposisi dalam implementasi PP Nomor 53 tahun 2010 tentang Disiplin Pegawai Negeri Sipil di Balai Latihan Kerja Mandiri Provinsi Jawa Barat sudah baik dilihat dari kemauan Pegawai Balai Latihan Kerja Mnadiri Provinsi Jawa Barat dalam mengikuti apel pagi, mematuhi jam kerja, dan melaksanakan tugas dengan penuh tanggungjawab.

\section{d. Struktur Birokrasi}

Untuk dimensi struktur birokrasi ini, penulis bagi ke dalam dua indikator yaitu Standar Operasional Prosedur (SOP) dan fragmentasi atau pola hubungan dalam penyelesaian masalah. Pertama, SOP dalam Implementasi PP Nomor 53 Tahun 2010 Tentang Disiplin Pegawai Negeri Sipil di Balai Latihan Kerja Mandiri Provinsi Jawa Barat. Berikut pernyataan dari Kepala BLKM Provinsi Jawa Barat:

"SOP tentu sudah sesuai dengan PP Nomor 53 taun 2010 tentang Disiplin PNS, tapi jikalau SOP pekerjaan kita punya SOP yang berbeda lagi standarnya yang ditentukan oleh Kepala Dinas yang sudah mencakup standarisasi kompetensi, skill tentunya. Yang di dalamnya telah kami sajikan secara lengkap dan jelas mengenai pelaksanaan tugas berkaitan dengan tupoksi pegawai masing-masing sesuai dengan bidangnya masingmasing." (Senin, 11 Maret 2019 Pukul 13.00 di BLKM Provinsi Jawa Barat).

Senada dengan pernyataan di atas, Ibu Heppy Sopiah, SH juga menyatakan bahwa dalam Standar Operating Procedur (SOP) Balai Latihan Kerja Mandiri Provnsi Jawa Barat sangat mengarahkan pegawai dalam melaksanakan tugas dan kerjanya dengan disiplin. Berikut yang dikemukakan oleh Ibu Heppy Sopiah, SH terkait SOP Balai Latihan Kerja Mandiri Provinsi Jawa Barat:

"Yang saya pribadi ketahui bahwa di dalam SOP BLKM itu memuat tentang uraian tugas kerja, di situ sudah teruraikan tersusun jelas sesuai bidang kerjanya masing-masing tentunya sangat mengarahkan pegawai dalam melaksanakan tugas dan kerjanya dengan disiplin dengan berpatokan pada SOP tersebut." (Senin, 11 Maret 2019 Pukul 14.30 di BLKM Provinsi Jawa Barat).

Sementara itu, Bapak Mulyana, S. menyatakan hal sebagai berikut:

"PP Nomor 53 tahun 2010 menurut saya di sini memang berjalan sesuai peraturan tersebut, namun berkaitan dengan SOP yang mana SOP BLKM di dalalamnya menguraikan tugas dan kerja daripada tiap-tiap biangnya, dengan SOP BLKM dengan menguraikan tugas kerja tersebut saya kira mendukung pegawai untuk melaksanakan tugas dan kerjanya sedisiplin mungkin." (Senin, 11 Maret 2019 Pukul 13.00 di BLKM Provinsi Jawa Barat). 
Kedua, fragmentasinya, Berikut pernyataan dari Kepala BLKM Provinsi Jawa Barat:

"Hubungan dalam mengatasi konflik atau masalah disiplin PNS, di pusat kan ada BKD yang mana Peran BKD provinsi Jawa Barat adalah sebagai penampung dari laporan-laporan mengenai disiplin, dalam hal ini kita menerima laporan bagaimana perkembangan pegawai di dalam melaksanakan kedisiplinan. Apabila terdapat pegawai yang melanggar peraturan disiplin, dilihat dulu bagaimana tingkat pelanggarannya yang selanjutnya dilakukan penanganannya sesuai dengan peraturan yang ada. Adapun di BLKM sendiri diatasi dahulu oleh atasan bidangnya, kemudian ke Subbag TU, kemudian masuk ke saya selaku Kepala Balai, jika memerlukan proses yang lebih lanjut maka akan masuk ke Dinas (Disnakertrans Provinsi Jawa Barat) dan baru diproses ke pusat." (Senin, 11 Maret 2019 Pukul 13.00 di BLKM Provinsi Jawa Barat).

Sementara itu, berikut ini adalah pernyataan dari Ibu Dra. Tuti Hidaryati mengenai pola hubungan dalam mengatasi masalah permasalahan yang ada berikut pernyataannya:

"Secara pembinaan ya dia pegawai yang melanggar dibina oleh atasannya terlebih dahulu. Pertama di panggil secara lisan, tetap melanggar pembinaan oleh atasan, $3 x$ juga masih oleh atasan, masih juga dan ke $4 x$ dia akan dipanggil oleh Kepala Balai. Adapun untuk sanksi di sini sudah sesuai dengan PP No 53 tahun 2010 tentang Disiplin PNS. Yakni untuk penanganan masalah yang berkaitan dengan disiplin PNS yakni dari atasan bidang, langsung k kabag TU, Kepala Balai, kemudian proses ke dinas, lalu ke pusat dan itu bukan poses yang cepat dan tidak semudah atasan bisa memecat pegawai yang melanggar disiplin PNS." (Senin, 11 Maret 2019 Pukul 13.30 di BLKM Provinsi Jawa Barat).

Dengan demikian, untuk dimensi struktur birokrasi dalam implementasi PP Nomor 53 tahun 2010 tentang Disiplin Pegawai Negeri Sipil di Balai Latihan Kerja Mandiri Provinsi Jawa Barat dapat dikatakan telah efektif karena Balai Latihan Kerja Mandiri Provinsi Jawa Barat telah mempunyai Standar Operasional Prosedur (SOP) dan prosedur fragmentasi yang jelas.

Selanjutnya berdasarkan pada analisis hasil penelitian, peneliti juga dapat menemukan beberapa faktor pendukung dalam implementasi PP Nomor 53 tahun 2010 tentang Disiplin Pegawai Negeri Sipil di Balai Latihan Kerja Mandiri Provinsi Jawa Barat. Adapun faktor pendukung tersebut adalah sebagai berikut:

1) Sarana dan Prasarana yang memadai

Sarana parasarana menjadi hal yang kursial dibutuhkan oleh suatu organisasi sebagai penopang telaksananya tujuan organisasi. Sarana dan prasarana di Balai Latihan Kerja Mandiri Provinsi Jawa Barat menjadi faktor pendukung dalam implementasi PP Nomor 53 tahun 2010 tentang Disiplin Pegawai Negeri Sipil. Di mana sarana dan prasarana yang dimaksud adalah seperti kendaraan dinas, finger print, suasana kantor yang nyaman, serta fasilitas mendukung dan memadai. Dengan adanya sarana dan prasarana tersebut merupakan modal awal bagi pembentukan pagawai negeri sipil yang efektif dan efisien demi terbentuknya suatu pegawai yang berjiwa disiplin tinggi serta taat pada tanggungjawab yang diberikan. 
Dengan demikian, aspek sarana dan prasarana memliki fungsi dan peran yang sangat penting dalam penegakkan disiplin Pegawai Negeri Sipil khususnya dalam implementasi PP Nomor 53 tahun 2010 tentang Disiplin Pegawai Negeri Sipil. Sebagaimana menurut Edward III dalam Widodo (2017) yang mengatakan keterbatasan sarana atau fasilitas menyebabkan gangguan untuk pelaksanaan suatu kebijakan.

\section{2) Penghargaan dan Insentif}

Kedisiplinan tidak dapat tercipta dengan sendirinya, akan tetapi selalu dilatar belakangi oleh faktor-faktor seperti adanya aturan yang mengatur, serta perasaan suka atau senang. Prasaan suka dan senang dapat muncul ketika pegawai mendapatkan penghargaan dari prestasi kerja. sehingga mereka termotivasi untuk bekerja dengan sebaik-baiknya sehingga mencapai hasil yang optimal. Penghargaan merupakan suatu motivasi yang kuat dalam meningkatkan kedisiplinan kerja maupun kinerja secara umum.

Di Balai Latihan Kerja Mandiri Provinsi Jawa Barat terlaksana dengan adanya penghargaan bagi pegawai yang memiliki tingkat disiplini yang tinggi dalam kurun waktu tertentu serta adanya pemberian Insentif Berbasis Kinerja (IBK) tiap bulannya bagi pegawai yang memiliki prestasi kerja dan disiplin yang baik. Tentunya hal tersebut sangat mendukung dan memotivasi pegawai dalam menegakkan peraturan disiplin.

Penting dalam organisasi untuk diadakannya penghargaan. Sebagaimana menurut Edward III dalam Widodo (2017) yang pada intinya enyatakan bahwa otivasi lahir didalam diri seseorang atas kehendaknya sendiri, dan penghargaan serta insentif mempengaruhinya.

3) Standar Operasional Prosedur (SOP) yang jelas

Dalam hal ini SOP Balai Latihan Kerja Mandiri Provinsi Jawa Barat yakni SOP BLKM Provinsi Jawa Barat tahun 2018 telah menguraikan tugas kerja pegawai secara rinci dan jelas sesuai dengan tufoksi masing-masing. Karena sejalan dengan teori Edward III di atas, yang mana SOP Balai Latihan Kerja Mandiri Provinsi Jawa Barat tersebut telah mengatur para pelaksana yakni para pegawai Balai Latihan Kerja Mandiri Provinsi Jawa Barat. Tidak hanya faktor pendukung, peneliti juga menemukan adanya beberapa faktor penghambat dalam implementasi PP Nomor 53 tahun 2010 tentang Disiplin Pegawai Negeri Sipil di Balai Latihan Kerja Mandiri Provinsi Jawa Barat. Faktor penghambat tersebut antara lain adalah sebagai berikut:

1) Minimnya intensitas pemerintah dalam mengadakan sosialisasi

Dalam penegakan hukum tentunya hal yang paling penting adalah pengetahuan pelaksana hukum atas hukum yang ada, sehingga hal ini menjadikan pentingnya sosialisasi bagi peningkatan pengetahuan para pelaksana hukum. Oleh karenanya, sosialisasi mengenai PP nomor 53 tahun 2010 tentang Disiplin Pegawai Negeri Sipil sangat diperlukan, untuk peningkatan pemahaman para pelaksana peraturan tersaebut. Pemimpin BLKM Provinsi Jawa Barat menyebutkan bahwa sosialisasi sering dilaksanakan. Namun secara pelaksanaannya belum diadakannya sosialisasi khusus untuk memberikan pemahaman kepada Pegawai. Hal ini tentunya menjadi salah satu penghambat dalam implementasi PP Nomor 53 tahun 2010 tentang Disiplin Pegawai Negeri Sipil. 
2) SDM dan kesiapan Pegawai Negeri Sipil belum memadai

Peneliti melihat bahwa terdapat kekurangan ketersediaan SDM dan kurangnya kesiapan pegawai dalam melaksanakan peraturan disiplin Pegawai Negeri Sipil. Hal ini bisa diketahui dari masih adanya pegawai Balai Latihan Kerja Mandiri Provinsi Jawa Barat yang belum sepenuhnya mematuhi jam kerja dan belum menggunakan jam kerja secara optimal.

\section{Simpulan}

Dapat kita tarik kesimpulan bahwa Implementasi Kebijakan Peraturan Pemerintah Nomor 53 Tahun 2010 Tentang Disiplin Pegawai Negeri Sipil di Balai Latihan Kerja Mandiri (BLKM) Provinsi Jawa Barat belum berjalan optimal, hal ini dikarenakan dilihat dari empat factor. Pertama, komunikasi sudah berjalan karena adanya pendistribusian peraturan tersebut sampai kepada staf atau pegawai. Kedua, sumber daya belum optimal karena walaupun sarana dan prasarana serta biaya dan anggaran telah menunjang sedangkan sumber daya manusia di Balai Latihan Kerja Mandiri Provinsi Jawa Barat belum menunjang hal ini karena jumlah pegawai masih kurang dan kesiapanya pun perlu ditingkatkan. Ketiga, disposisi sudah baik dilihat dari kemauan Pegawai Balai Latihan Kerja Mnadiri Provinsi Jawa Barat dalam mengikuti apel pagi, mematuhi jam kerja, dan melaksanakan tugas dengan penuh tanggungjawab. Keempat, struktur birokrasi dikatakan telah efektif karena Balai Latihan Kerja Mandiri Provinsi Jawa Barat telah mempunyai Standar Operasional Prosedur (SOP) dan prosedur fragmentasi yang jelas. Adapun untuk faktor pendukung implementasinya adalah terdiri dari sarana dan prasarana yang memadai, adanya penghargaan dan insentif, serta Standar Operasional Prosedur (SOP) yang jelas. Sedangkan faktor penghambatnya adalah rendahnya intensitas pemerintah dalam mengadakan sosialisasi, serta sumber daya manusia dan kesiapan Pegawai Negeri Sipil dalam melaksanakan peraturan disiplin belum memadai.

\section{Referensi}

Afifuddin. (2015). Manajemen Sumber Daya Manusia. Bandung: Pustaka Setia.

Agustino, L. (2014). Dasar-Dasar Kebijakan Publik, Bandung: Alfabeta

Anggara, S. (2015). Metode Penelitian Administrasi, Bandung: Pustaka Setia.

Budiman, R. (2015). Isu-isu Krusial Administrasi Publik Kontemporer. Bandung: Lepsindo.

Bungin, B. (2007). Penelitian Kualitatif: Komunikasi, Ekonomi, Kebijakan Publik, dan Ilmu Sosial Lainnya, Jakarta: Kencana.

Burhanuddin, A. (2005). Performance Apprasial. Jakarta: Rajawali Perss.

Dasimah, I. (2014), Pengaruh Implementasi Kebijakan PP No 53 Tahun 2010 Tentang Disiplin Pegawai Negeri Sipil (PNS) Terhadap Kinerja Pegawai di Kementerian Agama Kota Bandung, Bandung: FISIP UIN Sunan Gunung Djati Bandung.

Engkus, E (2017). Implementasi Undang-Undang Perdagangan Implikasinya Dalam Kebijakan Pengendalian Harga Kebutuhan Pokok Masyarakat, JISPO: Jurnal Ilmu Sosial dan Ilmu Politk, 18(1), 1-144.

Engkus, E. (2017). The Influence of Organizational Behavior on Work Ethics Employees In Bandung Regency Government. 1(1), 1-16. 
Edi, S, (2008). Analisis Kebijakan Publik. Bandung: Alfabeta.

Handoko, T.H. (2014). Manajemen Personalia dan Sumber Daya Manusia. Yogyakarta: BPFE.

Hidayat, dkk. (2017). Reformasi Administrasi: Teori dan Aplikasi. Bandung: FISIP UNPAS Press

Ishak, D., Maolani, D. Y., dan Engkus, E. (2017). Konsep Kinerja Dalam Studi Organisasi Publik. JISPO: Jurnal Ilmu Sosial dan Ilmu Politk, 7(2), 101-120.

Islami, I. (2009). Prinsip-Prinsip Perumusan Kebijaksanaan Negara, Jakarta: Bumi Aksara.

Moenir, HAS. (2002). Manajemen Pelayanan Publik, Jakarta: Bina Aksara.

Moleong, L. (2013). Meteologi Penelitian Kualitatif, Bandung: Remaja Rosdakarya.

Mulyawan, U. (2015). Implementasi Peraturan Pemerintah Nomor 53 Tahun 2010 Tentang Disiplin Pegawai Negeri Sipil (PNS) Di Badan Lingkungan Hidup Daerah Kota Serang, Serang: FISIP Universitas Sultan Ageng Tirtayasa.

Nawawi, I. (2009). PublicPolicy (Analisis, Strategi Advokasi Teori dan Praktek), Surabaya: PMN.

Nugroho, R. (2014). Public Policy, Jakarta: Elek Media Komputindo

Pasolong, H. (2013). Teori Administrasi Publik, Bandung: Alfabeta.

Peraturan Pemerintah Nomor 53 Tahun 2010 Tentang Disiplin Pegawai Negeri Sipil.

Purwanto, E.A., Sulistyastuti, D.R. (2017). Metode Penelitian Kuantitatif. Yogyakarta: Gava Media.

Saebani, B.A. (2012). Perbandingan Administrasi Negara. Bandung: Pustaka Setia.

Silalahi, U. (2012). Metode Penelitian Sosial, Bandung: Refika Aditama.

Soehartono, I. (2015). Metode Penelitian Sosial. Bandung: Remaja Rosdakarya.

Subarsono, A.G. (2013). Analisis Kebijakan Publik Konsep, Teori dan Aplikasi, Yogyakarta: Pustaka Pelajar.

Sugiyono. (2008). Metode Penelitian Bisnis, Bandung: Alfabeta.

Suyanto, B. (2013). Metode Penelitian Sosial Berbagai Alterntif Pendekatan, Jakarta: Prenada.

Syafiie, I.K. (2010). Pengantar Ilmu Pemerintahan. Jakarta: Refika Aditama.

Syafri, W. (2002). Studi Tentang Administrasi Publik. Jatinangor: Erlangga.

Wahab, S.A. (2008). Analisis Kebijaksanaan, dari Formulasi ke Implementasi. Jakarta: Bumi Aksara. . (2012). Pengantar Analisis Kebijakan Publik, Malang: UMM Press.

Widodo, J. (2017). Analisis Kebijakan Publik, Jakarta: MNC.

Winarno, B. (2004). Kebijakan Publik: Teori, Proses, dan Studi Kasus (Edisi dan Revisi Terbaru), Yogyakarta: CAPS.

Yenni Y.A. (2014). Implementasi Kebijakan Disiplin Pegawai Negeri Sipil di Dinas Pendidikan Provinsi Sulawesi Selatan, Makassar: FISIP Universitas Hasanudin. 